\title{
МІКРОБІолОГІя
}

DOI: $10.26693 / \mathrm{jmbs} 05.06 .231$

UDC 579.61:616.62-002] $=111$

Vynohradova K.', Gavrylyuk V. ${ }^{1}$, Khlopova O. $^{2}$, Pohorielova A.', Sklyar T. ${ }^{1}$, Sokolova I. ${ }^{1}$

\section{Monitoring of the Distribution of Antibiotic-Resistant Strains of Microorganisms - Causes of Infectious Processes of Urogenital Cystitis System of Patients}

\author{
1 Oles Honchar Dnipro National University, Dnipro, Ukraine \\ ${ }^{2}$ Medical-Diagnostic Center of the Medical Academy, Dnipro, Ukraine
}

kariandr98@gmail.com

The purpose of the work was to conduct a comparative analysis of the quantitative and qualitative composition of the microbiota of the urogenital system in different segments of the population of Dnipro for the period of 1 January - 31 August, 2020.

Material and methods. To study the microbial landscape and determine the levels of resistance to antimicrobial drugs variants of microorganisms circulating in the urogenital tract, were examined 176 people of different ages and genders - patients of the Medical Diagnostic Center at the Dnieper Medical Academy (Dnipro) for the period of 1 January - 31 August, 2020.

Results and discussion. According to the results of the microbiological study, the fact of development of infectious processes was established in 86 people, which accounted for $32.31 \%$ of cases. When studying the microbial landscape of the reproductive system of the examined patients, there was the following spectrum of priority pathogens of urogenital infections: in children and adolescents: Klebsiella oxytoca, Haemophilus influenzae / H. parainfluenzae, Escherichia coli, Streptococcus agalactiae; in women: Candida albicans, Streptococcus agalactiae, Escherichia coli, Ureaplasma spp.; in men: Ureaplasma spp. and Escherichia coli. During the monitoring of the proliferation of antibiotic-resistant variants of microorganisms - pathogens of infectious processes, the highest levels of resistance in isolated clinical isolates in relation to the drugs of classes were established: fluoroquinolons $-29.16 \%$, cephalosporins $-18.75 \%$ and carbopenems $-10.42 \%$ of cases.

Conclusion. With the use of test systems "Femoflor" and "Androflor" the species spectrum of pathogens of dysbiotic conditions of the urogenital tract in 88 patients aged 17-75 years with the help of polymerase chain reaction in real time was investigated.
The incidence of detection of conventional pathogenic and pathogenic microorganisms from the urogenital sphere of women and men and the ratio of aerobic and anaerobic microbiota in dysbiotic syndromes is shown. According to the results of the study, $60.97 \%$ of women and $76.59 \%$ of men had significant deviations toward reducing the titers of representatives of the symbiotic microbiota - bacteria of the genus Lactobacillus on the background of increasing quantitative indicators of conventional pathogenic microorganisms Gardnerella vaginalis etc., Eubacterium spp., Ureaplasma spp., Candida spp., Anaerococcus spp., Bacteroides spp. etc., Enterobacterium spp., and the presence of pathogenic microorganisms Mycopasma genitalium, Trichomonas vaginalis, Chlamydia trachomatis, Ureaplasma parvum in significant titras.

Keywords: urogenital tract, microbiota, antibiotic resistance, real-time polymerase chain reaction

Research relation to the programs, plans, and department themes. The work was carried out within the framework of the initiative topic "The biological basis of the functioning of the microbiocenoses of the environment and the human body", the State Registration Number is 0119 U 100097.

Introduction. In recent years, on the background of increasing urbanization, changes in lifestyle and living conditions, deteriorating environmental conditions, diet, hypovitaminosis and increasing the number of immunodeficiency conditions, the incidence of urogenital infections is growing [1]. Medical and socio-economic significance of inflammatory diseases of the urogenital tract of infectious origin due to global prevalence, a wide range of pathological conditions with a high frequency of residual manifestations, complications, reproductive or gestational dis- 
orders, the possibility of infection of newborns and the development of severe diseases in children [2]. The rapid growth of dysbiotic syndromes in the reproductive sphere remains a topical issue in scientific and medical practice. Biota imbalance is accompanied by immune and metabolic disorders, the severity of which can vary from asymptomatic carriers to severe clinical manifestations, which in turn contributes to the chronicity of the process, adverse effects on reproductive function and reduced quality of life [3-8]. Nowadays, numerous studies have shown that the etiological structure of urogenital infections is polymicrobial in nature and in some cases represented by associations of different species of microorganisms. The main issue is the timely detection of inflammation with the use of modern methods of laboratory diagnosis, the purpose of which is to prevent reproductive losses, opportunistic infections and dysbiosis [3-21]. The method of polymerase chain reaction in real time allows to detect pathogens even at low concentrations, to conduct etiological diagnosis in the early stages, to assess the qualitative and quantitative content of urogenital biocenosis, to control the quality of the bioassay and the effectiveness of therapy. Of all the available methods, the most complete range of microorganisms is presented in the tests "Femoflor" and "Androflor" [3-8]. One of the main problems of the XXI century is still the development of resistance to antibiotics in microorganisms of the genitourinary tract. Irrational antibiotic therapy significantly changes the biological properties of microorganisms and promotes the formation of populations of antibiotic-resistant variants. Therefore, the trigger for the reduction of genital pathology is the creation of proper monitoring, an effective system of prevention and adequate treatment with chemotherapeutic drugs [3-8, 10-21].

The purpose and objectives of the study. In view of the above, the purpose of the work was to conduct a comparative analysis of the quantitative and qualitative composition of the microbiota of the urogenital system in different segments of the population of Dnipro for the period of 1 January - 31 August, 2020.

Material and methods. Studies of the composition of the microbiota on quality and quantitative indicators were performed by methods of bacteriological analysis, species identification of isolated clinical isolates of Enterobacteriaceae spp. and other gram-negative rods were determined using test kits "API 20E" ("BioMerieux", France), non-fermentable gram-negative rods of the genus Pseudomonas - for "API 20 NE" ("BioMerieux", France), staphylococci for "API Staph" ("BioMerieux", France), streptococci and enterococci according to" API 20 Strep" ("BioMerieux", France), other types of microorganisms - representatives of normal, opportunistic aerobic and anaerobic microbiota were performed according to the schemes of identification of bacteria by Bergie bacterium [22]. Levels of resistance to antibiotics were determined by disco-diffusion method. Sensitivity assessment of isolated strains of microorganisms was performed according to the criteria of CLSI / NCCLS [23].

The experiments used test systems "Femoflor-16" and "Androflor" in Real time mode, which allowed to obtain a complete quantitative characterization of the microbiome and to differentiate the states of physiological balance or dysbiosis. When isolating DNA used standard sets of reagents - RealBest DNA extraction 3, lysing solution (JSC "VectorBest", Russia), TEST-NK (LLC "NPO DNA-Technology", Russia). When determining the microbial landscape, a set of reagents was used to study the biocenosis of the urogenital tract in women and men by real-time PCR ("Femoflor-16" and "Androflor") and a detecting amplifier DT-96 / DT-322 manufactured by NPO DNA Technology »(RF).

To obtain adequate results, only samples with a sufficient number of cells in a test tube with the analyzed sample and sufficient total bacterial mass were used. Samples in which the number of human DNA cells was more than $10^{4}$ genome equivalents (GE) in the sample and the value of the total bacterial mass ranged from $10^{6}$ to $10^{9} \mathrm{GE} /$ sample were considered. When the value of the control of material uptake (KVM) is less than $10^{4}$, the result of PCR analysis of biota is considered inaccurate, which requires re-capture of biomaterial.

Accounting and processing of results was performed automatically using the standard Microsoft Office Excel package. All examined patients signed an informative consent, the study was conducted in accordance with the Declaration of Helsinki of the World Medical Association, the Statute of the Ukrainian Association of Bioethics, standard provisions on ethics of the Ministry of Health of Ukraine №66 of February 13,2006 . Diagnosis of urogenital infections research methods, in accordance with the recommendations of the American Association of Microbiologists (ASM) and the European Association of Urologists (EAU) $[24,25]$.

Results and discussion. To study the microbial landscape and determine the levels of resistance to antimicrobial drugs variants of microorganisms circulating in the urogenital tract, were examined 176 people of different ages and genders - patients of the Medical Diagnostic Center at the Dnieper Medical Academy (Dnipro) for the period of 1 January - 31 August, 2020.

According to the results of a comprehensive study, the fact of the presence of an infectious process in 84 people was established, which was $32.31 \%$ of cases (Table 1). To conduct a comparative analysis of the incidence of urogenital infections during the study period, patients of three groups were 
Table 1 - Indicators of infection of the urogenital tract of patients of different ages and sex for the period of 1 January - 31 August, 2020

\begin{tabular}{|c|c|c|c|c|c|}
\hline \multicolumn{2}{|c|}{ Results } & $\begin{array}{c}\text { Children } \\
\text { and } \\
\text { adolescents }\end{array}$ & Women & Men & Total \\
\hline \multirow{2}{*}{ examined } & absolutely & 59 & 63 & 54 & 176 \\
\cline { 2 - 6 } & percent & $33.52 \%$ & $35.79 \%$ & $30.68 \%$ & $67.69 \%$ \\
\hline \multirow{2}{*}{ infected } & absolutely & 20 & 41 & 23 & 84 \\
\cline { 2 - 6 } & percent & $23.81 \%$ & $48.81 \%$ & $27.38 \%$ & $32.31 \%$ \\
\hline
\end{tabular}

from 10.0 to $25.0 \%$, Escherichia coli - up to $20.0 \%$, Streptococcus agalactiae - up to $15.0 \%$ of cases, Streptococcus pyogenes, Staphylococcus aureus, Proteus spp., Streptococcus anginosus group up to $5.0 \%$ of cases in this age group [18-21, 26].

As a result of examination of 63 women in $41(48.81 \%)$ persons the development of inflammatory processes examined: 1) children and adolescents under 16 years $(n=59), 2)$ women $(n=63), 3)$ men $(n=54)$. Each group of patients was divided into age categories: 1) children and adolescents: I - children from 1 to 5 years ( $n=17)$; II - from 6 to 10 years $(n=32)$; III - from 11 to 16 years $(\mathrm{n}=10)$; 2) women: I - from 17 to 35 years ( $n=34)$; II - from 36 to 55 years $(n=19)$; III - from 56 to 75 years $(n=10)$; 3 ) men: I - from 17 to 35 years ( $n=22)$; II - from 36 to 55 years $(n=19)$; III - from 56 to 75 years $(n=13)$.

Examination of 59 children and adolescents during the study period showed that 20 patients $(23.81 \%)$ in the genitourinary tract circulating microorganisms - pathogens of infectious processes, namely: Klebsiella oxytoca - 25.49\%, Haemophilus influenzae / H. parainfluenzae - 19, 61\%, Escherichia coli-15.68\%, Streptococcus agalactiae - 13.73\%, Streptococcus pyogenes - 7.84\%, Staphylococcus aureus, Proteus spp., Streptococcus anginosus group $-5.88 \%$ of cases (Table 2). The obtained data coincided with the data of the authors Rampersaud $R$ et al., Reid G et al., Moreno I et al., Franasiak JM et al., who noted the presence of microorganisms of the species: Klebsiella oxytoca - from 15.0 to $30.0 \%$ of cases, Haemophilus influenzae / H. parainfluezae -

Table 2 - Frequency of excretion of uropathogenic microorganisms from children and adolescents

\begin{tabular}{|l|c|c|c|}
\hline \multirow{2}{*}{ Type of microorganism } & \multicolumn{3}{|c|}{$\begin{array}{c}\text { Indicators of isolation } \\
\text { of opportunistic } \\
\text { and pathogenic } \\
\text { microorganisms from } \\
\text { children } \\
\text { of different ages (\%) }\end{array}$} \\
\hline & $\mathbf{1 - 5}$ & $\mathbf{6 - 1 0}$ & $\mathbf{1 1 - 1 6}$ \\
\hline Escherichia coli & $6.25 \%$ & $25.0 \%$ & $9.09 \%$ \\
\hline Klebsiella oxytoca & $12.50 \%$ & $33.33 \%$ & $27.27 \%$ \\
\hline Proteus spp. & $6.25 \%$ & $4.16 \%$ & $9.09 \%$ \\
\hline Staphylococcus aureus & $12.50 \%$ & $4.16 \%$ & - \\
\hline Streptococcus pyogenes & $6.25 \%$ & $12.50 \%$ & - \\
\hline Streptococcus agalactiae & $18.75 \%$ & $8.33 \%$ & $18.18 \%$ \\
\hline $\begin{array}{l}\text { Streptococcus anginosus } \\
\text { group }\end{array}$ & $6.25 \%$ & $4.16 \%$ & $9.09 \%$ \\
\hline $\begin{array}{l}\text { Haemophilus influenzae/ } \\
\text { H. parainfluenzae }\end{array}$ & $31.25 \%$ & $8.33 \%$ & $27.27 \%$ \\
\hline TOTAL & $31.97 \%$ & $47.06 \%$ & $21.57 \%$ \\
\hline
\end{tabular}

with such pathogens as (Table 3): Candida albicans $24.64 \%$, Streptococcus agalactiae - 14.49\%, Escherichia coli - $13.04 \%$, Ureaplasma spp. - 11.59\%, Mycoplasma hominis - 5.79\%, Klebsiella spp., Proteus spp., Enterococcus faecalis, Staphylococcus aureus, Streptococcus anginosus group, Enterobacter spp. - 4.35\% each, Candida tropicalis, Candida spp. $2.89 \%$, Candida glabrata, Candida krusei $-1.45 \%$ of cases. In studies by Peric A et al., Linhares IM et al., Witkin S et al., Marchesi JR et al., and Dasari S et al. the frequency of infection of women of reproductive age is shown: Candida albicans - up to $30.0 \%$ of cases, Streptococcus agalactiae, Escherichia coli, Ureaplasma spp. - up to $20.0 \%$ of cases [27-31].

The examination of 54 men showed that 23 patients $(27.38 \%)$ were infected with urogenital diseases, such as (Table 3): Ureaplasma spp. - 16.0\%, Escherichia coli - 12.0\%, Candida albicans, Enterobacter spp. $-9.33 \%$ of cases, Proteus spp., Streptococcus agalactiae, Mycoplasma hominis - $8.0 \%$ of cases, Enterococcus faecalis, Staphylococcus aureus $-5.33 \%$ of cases, Klebsiella spp., Streptococcus anginosus group, Candida tropicalis, Candida glabrata $-4.0 \%$, Candida krusei, Candida spp. - 1.33\% of cases. Similar data were obtained by Mändar $R$, De Francesco MA et al., Askienazy-Elbhar M, Purvis $\mathrm{K}$ et al., who noted the frequency of lesions of the male genital area by opportunistic pathogens when examining patients of reproductive age: Ureaplasma spp. - up to $25.0 \%$, Escherichia coli - up to $20.0 \%$, Streptococcus agalactiae, Enterobacter spp., Proteus spp., Mycoplasma hominis and Candida albicans - up to $10.0 \%$ of cases [32-35].

In order to determine the spectrum of pathogens of urogenital infections, the frequency of microbial agents isolated from patients of different categories was monitored. During the study period, bacteria of the following species were isolated: Escherichia coli $-13.0 \%$ of cases, Streptococcus agalactiae $11.79 \%$, Candida albicans - 10.77\%, Ureaplasma spp. $-10.26 \%$, Klebsiella oxytoca $-6.66 \%$, Proteus spp. $-6.15 \%$, Staphylococcus aureus, Haemophilus influenzae / H. parainfluenzae, Enterobacter spp., Mycoplasma hominis - 5.13\%, Streptococcus anginosus group - 4.62\%, Enterococcus faecalis - 3.59\%, Klebsiella spp. $-3.07 \%$, Candida tropicalis $-2.56 \%$, 
Table 3 - Frequency of excretion of uropathogenic microorganisms from women and men

\begin{tabular}{|c|c|c|c|c|c|c|}
\hline \multirow[t]{2}{*}{ Type of microorganism } & \multicolumn{3}{|c|}{$\begin{array}{l}\text { Indicators of isolation of opportu- } \\
\text { nistic and pathogenic microorgan- } \\
\text { isms from women of different ages } \\
(\%)\end{array}$} & \multicolumn{3}{|c|}{$\begin{array}{l}\text { Indicators of isolation of opportu- } \\
\text { nistic and pathogenic microorgan- } \\
\text { isms from men of different ages } \\
(\%)\end{array}$} \\
\hline & 17-35 & $36-55$ & $56-75$ & $17-35$ & $36-55$ & $56-75$ \\
\hline Escherichia coli & $12.91 \%$ & $18.18 \%$ & $6.25 \%$ & $20.0 \%$ & $10.34 \%$ & - \\
\hline Klebsiella spp. & $3.23 \%$ & $4.55 \%$ & $6.25 \%$ & $3.33 \%$ & $3.45 \%$ & $6.25 \%$ \\
\hline Proteus spp. & $3.23 \%$ & $4.55 \%$ & $6.25 \%$ & $6.66 \%$ & $6.89 \%$ & $12.50 \%$ \\
\hline Enterococcus faecalis & $3.23 \%$ & $4.55 \%$ & $6.25 \%$ & $3.33 \%$ & $10.34 \%$ & - \\
\hline Staphylococcus aureus & $3.23 \%$ & $4.55 \%$ & $6.25 \%$ & $6.66 \%$ & $3.45 \%$ & $6.25 \%$ \\
\hline Streptococcus agalactiae & $6.45 \%$ & $13.64 \%$ & $31.25 \%$ & $10.0 \%$ & $3.45 \%$ & $12.50 \%$ \\
\hline Streptococcus anginosus group & $3.23 \%$ & $4.55 \%$ & $6.25 \%$ & $3.33 \%$ & $3.45 \%$ & $6.25 \%$ \\
\hline Enterobacter spp. & $3.23 \%$ & $4.55 \%$ & $6.25 \%$ & $3.33 \%$ & $10.34 \%$ & $18.75 \%$ \\
\hline Ureaplasma spp. & $16.31 \%$ & $9.09 \%$ & $6.25 \%$ & $16.66 \%$ & $17.24 \%$ & $12.50 \%$ \\
\hline Mycoplasma hominis & $3.23 \%$ & $9.09 \%$ & $6.25 \%$ & $10.0 \%$ & $6.89 \%$ & $6.25 \%$ \\
\hline Candida albicans & $25.81 \%$ & $18.18 \%$ & $12.50 \%$ & $6.66 \%$ & $13.79 \%$ & $6.25 \%$ \\
\hline Candida tropicalis & $6.45 \%$ & - & - & $3.33 \%$ & $3.45 \%$ & $6.25 \%$ \\
\hline Candida glabrata & $3.23 \%$ & - & - & $3.33 \%$ & $3.45 \%$ & $6.25 \%$ \\
\hline Candida krusei & $3.23 \%$ & - & - & $3.33 \%$ & - & - \\
\hline Candida spp. & $3.23 \%$ & $4.55 \%$ & - & - & $3.45 \%$ & - \\
\hline TOTAL & $44.93 \%$ & $31.88 \%$ & $23.18 \%$ & $40.0 \%$ & $38.66 \%$ & $21.33 \%$ \\
\hline
\end{tabular}

Streptococcus pyogenes, Candida glabrata $-2.05 \%$, Candida spp. $-1.54 \%$, Candida krusei $-1.06 \%$ of cases (Fig. 1).

As a result of the conducted research it is possible to define the priority activators which most often cause defeats of a urogenital tract of persons of different age categories and sex: Escherichia coli, Streptococcus agalactiae, Candida albicans and Ureaplasma spp.

The next stage of the study was to analyze the resistance of selected strains of uropathogenic microorganisms to antibacterial drugs, as the problem of antibiotic resistance, according to World Health Experts (WHO), the scale of the pandemic: the world has confidently entered the postantibiotic era. And taking into account the enormous damage caused by

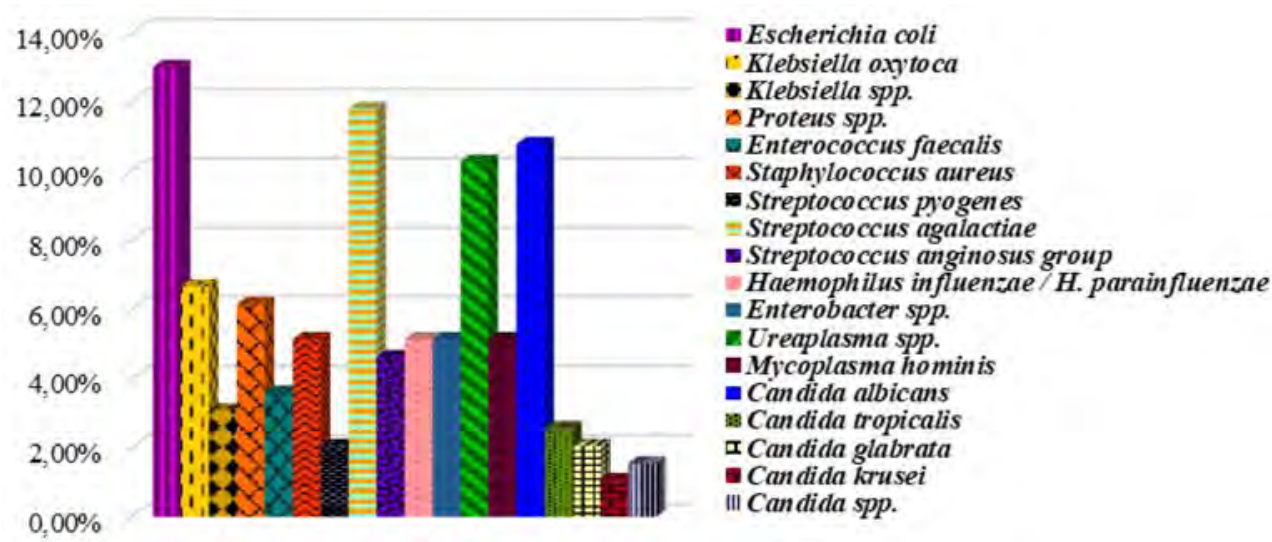

Fig. 1. Species spectrum of microorganisms isolated from the urogenital system of patients of different ages and sex inadequate antibiotic therapy, researchers around the world agree that antibiotics should be preferred rather than broad-spectrum antibiotics, and if there is an effective alternative, it should be taken into account. Today, data on the etiological structure, susceptibility of pathogens to antibacterial drugs in the world differ, which indicates the need to study the regional features of antibiotic resistance. The increase in the number of patients with urogenital infections, the difficulties of therapy associated with antibiotic resistance, the complexity and ambiguity of many issues of the mechanism of the disease, the lack of clear criteria for diagnosis and impact of infection on the reproductive system, make this problem extremely relevant. The urgency of the problem of the spread of antibiotic-resistant strains of microorganisms - pathogens of urogenital tract infections reaches its incredible peak during treatment, which often leads to the development of recurrent infections and pathological changes in the tissues of the genitourinary tract. The presence or absence of complicating factors in patients with urogenital tract infections is one of the key parameters 
determining the characteristics of patient supervision and choice of therapy. The microbiological features of complicated infections include: a wider range of pathogens and a high frequency of excretion of resistant bacteria in relation to uncomplicated urogenital infections [36-38].

According to the results of the research, 96 antibiotic-resistant variants from 195 isolated cultures of opportunistic and pathogenic microorganisms were identified.

The highest levels of resistance in the studied cultures of microorganisms were found in relation to drugs of the class: fluoroquinolones $-29.16 \%$ of cases, cephalosporins $-18.75 \%$ and carbopenems $10.42 \%$; lower rates were recorded for penicillins $9.37 \%$, tetracyclines $-8.33 \%$, monobactams $-7.29 \%$, aminoglycosides $-6.25 \%$, macrolides $-5.21 \%$, lincosamides $-3.13 \%$, sulfonamides $-2.08 \%$ of cases (Fig. 2).

The main mechanisms of resistance of classical bacteria to fluoroquinolones are connected with

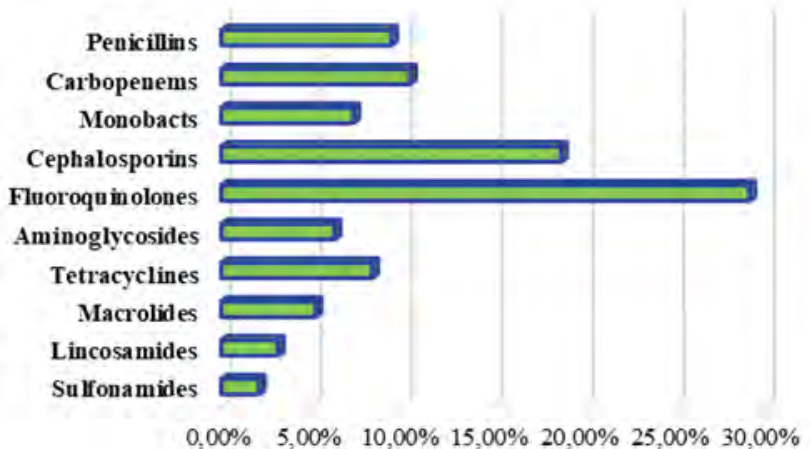

Fig. 2. Determination of the degree of resistance to antibiotics in uropathogenic strains of microorganisms

change of structure of two bacterial enzymes on which these antibiotics - DNA gyrase and topoisomerase IV which are responsible in a bacterial cell for the conformational changes of DNA necessary for its normal replication, and also from modification. targets as a result of mutations in the QRDR (Quinolone Resistance-Determing Region) of target genes, as well as with a decrease in the accumulation of drugs in the cell and the acquisition of determinants of resistance by horizontal gene transfer. Bacterial resistance to cephalosporin drugs is due to one of the mechanisms: 1) modification of peptidoglycan, which leads to a decrease in the effectiveness of the drug; 2) hydrolysis activation of the antibiotic by beta-lactamases; 3 ) violation of the permeability of the external structures of the microbial cell and the difficulty of binding of the antibiotic to the peptidoglycan. Resistance to carbapenems can be caused by various mechanisms, in particular: changes in the permeability of the out- er cell membrane, activation of efflux systems or the production of hydrolyzing carbapenems $\beta$-lactamases (carbapenemases) [39-42].

The obtained data correlate with the results of studies by Komolafe OO, Amyes S.G.B., Laxminarayan R., Malik B. et al. and Martinez J. L. et al., who noted the highest levels of resistance in clinical isolates of uropathogenic microorganisms to antibiotics of classes: fluoroquinolones - up to $35.0 \%$, cephalosporins - up to $25.0 \%$ and carbopenems - up to $20.0 \%$ of cases [43-47].

Increasingly, scientists are noticing a rapid growth of dysbiotic disorders of the urogenital system in both women and men. Therefore, in today's conditions, urogenital imbalance is an urgent problem in clinical microbiology, given that not all the mechanisms of dysbiotic conditions are fully understood, there are no clear diagnostic criteria, difficulties in selecting effective therapy due to antibiotic resistance.

In the process of studying the state of the microbiota of the urogenital system of 41 women of different ages by real-time PCR, the fact of the presence of dysbiotic disorders in $25(60.97 \%)$ patients was established.

Examination of 47 males in $36(76.59 \%)$ patients revealed dysbiotic disorders in the urogenital tract.

It should be noted that the state of microbial coenosis of the reproductive system of women and men is influenced by a number of different environmental factors - environmental, climatic, sanitary and epidemiological, stress, sexual activity, drugs, invasive manipulations, surgery and more.

Dysbiotic conditions in the examined patients were established by quality and qualitative indicators of the presence of certain representatives of the microbiome of the urogenital system. As a result of real-time PCR analysis in the vast majority of patients revealed a significant decrease in titers of Lactobacillus - the main symbionts of the genital habitat of women from 0 to $10^{6} \mathrm{CFU} / \mathrm{ml}$ at a rate of $10^{7}-10^{9}$ CFU / ml: $68.0 \%$ of cases (Fig. 3).

Among the representatives of the obligate anaerobic microbiota, the titers of which should not exceed the permissible values $<10^{4}-10^{5} \mathrm{CFU} / \mathrm{ml}$, significant deviations in the direction of increasing the quantitative indicators to $10^{6}-10^{9} \mathrm{CFU} / \mathrm{ml}$ : Gardnerella vaginalis / Prevotella bivia / Porhyromonas spp. $-56.0 \%$ of cases, Eubacterium spp. - 52.0\%, Atopobium vaginae - 48.0\%, Megasphera spp. / Velionella spp. I Dialister spp. - 24.0\%, Sneathia spp. / Leptotrihia spp. / Fusobacterium spp. - 20.0\%, Peptostreptococcus spp. $-16.0 \%$, Lachnobacterium spp. / Clostridium spp. $-12.0 \%$ and Mobiluncus spp. / Corynebacterium spp. $-8.0 \%$ of cases.

It should be noted that the bacteria of the species Ureaplasma spp., Gardnerella vaginalis etc. and 

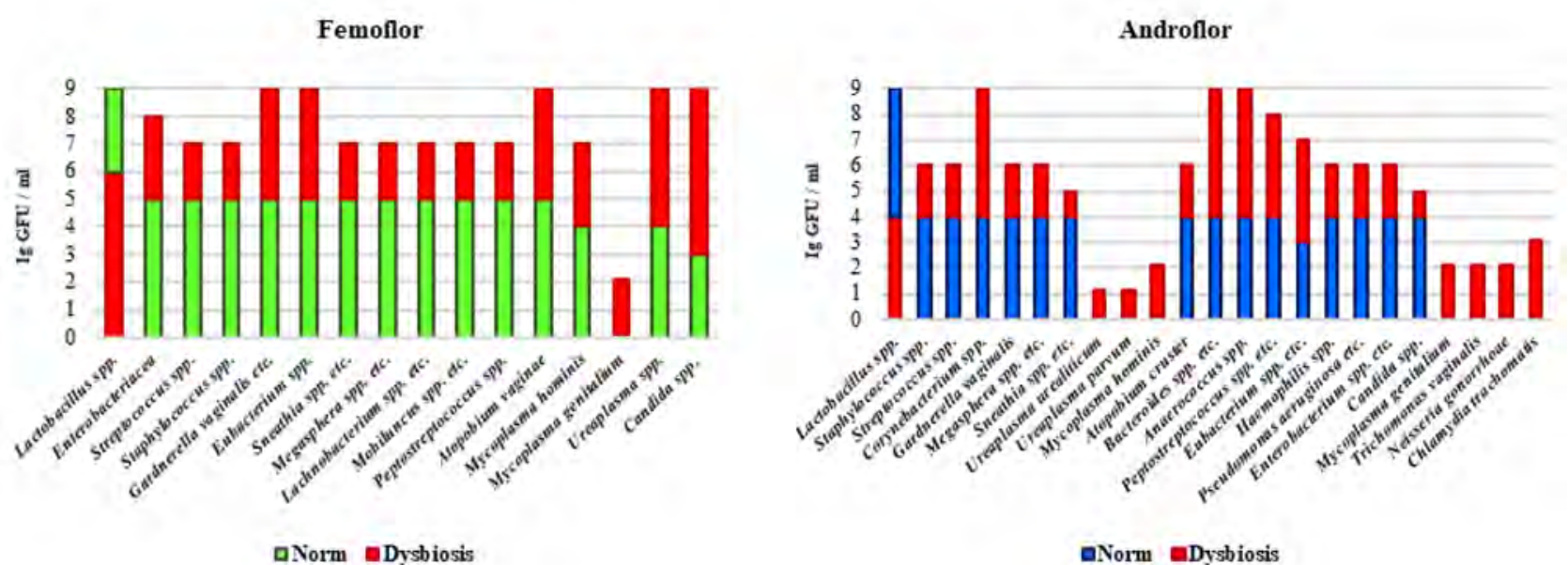

Fig. 3. Indicators of deviation of titers of microorganisms - representatives of the microbiome of the urogenital system of females and males

Eubacterium spp. during the study period were detected with almost the same frequency, which confirms their role in the development of dysbiotic disorders. There is also a high degree of colonization by fungi of the genus Candida urogenital habitat of the studied patients, which may indicate a decrease in immune status, changes in the physiological and hormonal status of the macroorganism and the presence or transmission of chronic diseases.

The presented data coincide with the studies of other authors: Gergova R. T. et al., who noted a significant deviation from the norm of Gardnerella vaginalis to $10^{6}-10^{8} \mathrm{CFU} / \mathrm{ml}$ in $35.0-70.0 \%$ of patients [48]. Teixeira G. S. et al. recorded an increase in G. vaginalis titer to $10^{6}-10^{9} \mathrm{CFU} / \mathrm{ml}$ in $56.7 \%$ of women with urogenital inflammation and in $17.6 \%$ without health complaints [49]. Janulaitiene $M$. et al. noted the presence of $\mathrm{G}$. vaginalis in the titer of $10^{6}-10^{7} \mathrm{CFU} / \mathrm{ml}$ in $45.8-68.3 \%$ of women [50]. The data obtained correlate with the results of a study by Gruzevsky O. A. et al., who noted the predominance of obligate anaerobic bacteria G. vaginalis (69.2\% of cases), Eubacterium spp. (69.8-79.7\%), Ureaplasma spp. (45.3\%) in healthy patients from 18 to 52 years and from 16 to 64 years with existing infectious-inflammatory processes in the vagina [51]. Manzoor S. et al. noted steady growth of yeast-like fungi of the genus Candida (up to $30.0 \%$ ) in patients aged 18 to 41 years [52]. According to studies by Okodo M. et. al., who noted that with age the level of estrogen and the number of Lactobacillus decreases, which causes a gradual increase in $\mathrm{pH}$ to neutral, and this stimulates an increase in the number of yeasts and contamination with opportunistic and pathogenic biota agents [54].

For the male sexual sphere, the state of the normocenosis is provided by the bacteria of the species Lactobacillus spp. - $10^{4} \mathrm{CFU} / \mathrm{ml}$ and more, Staphylococcus spp., Streptococcus spp., Corynebacterium spp. in titers not more than $10^{4} \mathrm{CFU} / \mathrm{ml}$. More than half of the examined male patients showed deviations in normobiota in the direction of reducing the number of Lactobacillus spp. from 0 to $10^{3} \mathrm{CFU} / \mathrm{ml}-77.77 \%$ of cases (Fig. 3).

Obligatory-anaerobic microorganisms with a high frequency were isolated in significant quantities $10^{4}$ $10^{9} \mathrm{CFU} / \mathrm{ml}$ at an acceptable rate of not more than 103-10 CFU / ml: Bacteroides spp. / Prevotella spp. I Porhyromonas spp. - 91.66\%; Peptostreptococcus spp. / Parvimonas spp. - 86.11\%; Eubacterium spp. - 80.55\%; Megasphera spp. / Veilonella spp. / Dialister spp. - 19.44\%; Gardnerella vaginalis - $16.66 \%$; Sneathia spp. / Leptotrichia spp. / Fusobacterium spp. and Atopobium cruster $-5.55 \%$ of cases.

Detection rates of aerobic and facultative anaerobic microbiota also had deviations from $10^{5}-10^{9} \mathrm{CFU}$ / $\mathrm{ml}$ compared with the permissible values of not more than $10^{4} \mathrm{CFU} / \mathrm{ml}$ : Anaerococcus spp. - 94.44\%; Corynebacterium spp. - 47.22\%; Streptococcus spp. 30.55\%; Enterobacterium spp. - 25.0\%; Staphylococcus spp. - 22.22\%; Haemophilus spp. - 8.33\%; Pseudomonas aeruginosa / Ralstonia spp. / Durkholderia spp. $-5.55 \%$ of cases.

Real pathogens were isolated in titers of $10^{1}-10^{3}$ $\mathrm{CFU} / \mathrm{ml}$ from some patients. Their presence is not allowed at all reference values: Trichomonas vaginalis - 19.44\%; Chlamydia trachomatis and Ureaplasma parvum - 11.11\%; Neisseria gonorrhoae and Ureaplasma urealyticum - 8.33\%; Mycoplasma genitalium and Mycoplasma hominis $-5.55 \%$ of cases. The detection rates of yeast-like fungi of the genus Candida significantly exceeded the norm (not more than $10^{4} \mathrm{CFU} / \mathrm{ml}$ ) to $10^{5} \mathrm{CFU} / \mathrm{ml}$ in $2.77 \%$ of cases.

According to the results of real-time PCR studies using the test system "Androflor" showed significant changes in the microbiome of the male reproductive system due to excessive growth of opportunistic and pathogenic microorganisms against the background 
of reducing the number or complete elimination of symbiotic bacteria.

The results of the studies correlate with the data obtained by Okodo M. et al. and Kiessling A. A. et al., which noted significant deviations in the direction of increasing the quantitative indicators of obligate anaerobic $\left(10^{4}-10^{9} \mathrm{CFU} / \mathrm{ml}\right)$ and facultative anaerobic $\left(10^{5}-10^{9} \mathrm{CFU} / \mathrm{ml}\right)$ representatives, namely Anaerococcus spp. in $55.0-95.0 \%$, Bacteroides spp. etc. in 40.0-90.0\%, Peptostreptococcus spp. etc. in 45.0$85.0 \%$, Eubacterium spp. in $55.0-80.0 \%$ patients [54].

\section{Conclusion}

1. In the study of the microbial landscape of the reproductive tract of the examined patients, a range of priority pathogens of urogenital infections was determined: in children and adolescents - Klebsiella oxytoca, Haemophilus influenzae / H. parainfluenzae, Escherichia coli, Streptococcus agalactiae; in women - Candida albicans, Streptococcus agalactiae, Escherichia coli, Ureaplasma spp.; in men - Ureaplasma spp. and Escherichia coli.

2. According to the results of monitoring the spread of antibiotic-resistant variants of uropathogenic microorganisms, the highest levels of resistance in the studied cultures of microorganisms were recorded in relation to drugs of fluoroquinolones, cephalosporins and carbopenems classes.

3. As a result of real-time PCR analysis of the composition of the microbiome of the urogenital tract dysbiotic disorders were caused by falling titers of bacteria Lactobacillus and excessive colonization of opportunistic and pathogenic microorganisms: in the female sphere Ureaplasma spp., Gardnerella vaginalis etc., Eubacterium spp. and yeast-like fungi of the genus Candida; in the urogenital system of men - Anaerococcus spp., Bacteroides spp. etc., Enterobacterium spp.; as well as the presence of real pathogens - Mycopasma genitalium in females and Trichomonas vaginalis, Chlamydia trachomatis, Ureaplasma parvum, Mycopasma genitalium in males.

Prospects for further research. The data was obtained from continuous microbiological monitoring of infectious processes and dysbiotic conditions, as well as the spread of antibiotic-resistant variants of opportunistic and pathogenic microorganisms in the urogenital system in different segments of the population. This determines the need to improve and develop new diagnostic tools, corrective and therapeutic measures to improve the health of the population.

\section{References}

1. Vyalov SS. Diagnostika i lechenie urogenitalnykh infektsiy $v$ obshchey praktike [Diagnosis and treatment of urogenital infections in general practice]. Arkh vnutr med. 2012; 3(3): 20-6. [Russian]

2. Goncharenko VV. Mikrobiologichniy monitoring infektsiy urogenitalnogo traktu $v$ umovakh venerologichnoyi kliniki [Microbiological monitoring of infections of the urogenital tract in the minds of a venereologic clinic]. Dermatologiya ta venerologiya. 2014; 4(1): 44-53. [Ukrainian]

3. Magistro G, Stief CG. The urinary tract microbiome: the answer to all our open questions? Eur Urol. 2018; 5(1): 36-8.

4. Aragón IM, Herrera-Imbroda B, Queipo-Ortuño MI, Castillo E, Del Moral JS, Gómez-Millán J, et al. The Urinary Tract Microbiome in Health and Disease. Eur Urol. 2018; 4(1): 128-38.

5. Whiteside SA, Razvi H, Dave S, Reid G, Burton JP. The microbiome of the urinary tract - a role beyond infection. Nat Rev Urol. 2018; 12(1): 81-90.

6. Wolfe AJ, Brubaker L. "Sterile urine" and the presence of bacteria. Eur Urol. 2018; 68(1): 173-4.

7. Brubaker L, Wolfe AJ. The new world of the urinary microbiota in women. Am J Obstet Gynecol. 2015; 213(1): 644-9.

8. Schneeweiss $\mathrm{J}$, Koch M, Umek W. The human urinary microbiome and how it relates to urogynecology. Int Urogynecol J. 2016; 27(1): 1307-12.

9. Radzinskiy VE, Khamoshina MB, Kaygorodova LA. Korrektsiya narusheniy biotsenoza vlagalishcha - marsh na meste ili dvizhenie vpered? [Correction of violations of the vaginal biocenosis - marching in place or moving forward?]. Reproduktivnaya endokrinologiya. 2014; 4(18): 92-100. [Russian]

10. Gottschick C, Deng ZL, Masur C, Abels C, Pieper DH, Wagner-Döbler I. The urinary microbiota of men and women and its changes in women during bacterial vaginosis and antibiotic treatment. Microbiome. 2017; 5 (99): 1-15.

11. Bao Y, Al KF, Chanyi RM, Whiteside S, Dewar M, Razvi H, et al. Questions and challenges associated with studying the microbiome of the urinary tract. Ann Trans/ Med. 2017; 5(2): 33-6.

12. Prestinaci F, Pezzotti P, Pantosti A. Antimicrobial resistance: a global multifaceted phenomenon. Pathog Glob Health. 2015; 109(1): 309-18.

13. Richard JF, Yitzhak T. Antibiotics and bacterial resistance in the 21st century. Perspect Medicin Chem. 2014; 6(1): 25-64. 
14. Cosgrove SE, Carmeli Y. The impact of antimicrobial resistance on health and economic outcomes. Clinical Infect Dis. 2003; 36(1): 1433-7.

15. Friedman ND, Temkin E, Carmeli Y. The negative impact of antibiotic resistance. Clin Microbiol Infect. 2016; 22(1): 416-22.

16. Yusuf EO, Kemjou TS. Antibiotic resistance among genital tract isolates from sexually-transimitted disease patients. Med Lab Sci J. 2005; 14(1): 63-8.

17. Amin ET, Njumkeng C, Kika BT, Fualefac A, Njukeng P. Pattern of antimicrobial resistance among bacterial isolates from urogenital clinical specimens: a descriptive study from the Buea Health District, Cameroon. Drugs-Real World Outcomes. 2018; 5(1): 101-8.

18. Rampersaud R, Randis TM, Ratner AJ. Microbiota of the upper and lower genital tract. Semin. Fetal Neonatal Med. 2012; 17(1): 51-7.

19. Moreno I, Simon C. Deciphering the effect of reproductive tract microbiota on human reproduction. Reprod Med Biol. 2019; 18(1): 40-50.

20. Franasiak JM, Scott RT. Introduction: microbiome in human reproduction. Fertil Steril. 2015; 104(6): $1341-3$.

21. Franasiak JM, Scott RT. Reproductive tract microbiome in assisted reproductive technologies. Fertil Steril. 2015; 104(6): 1364-71.

22. Whitman WB, Holt JG. Bergey's manual of systematic bacteriology. 9th ed. Philadelphia: Lippincott Williams \& Wilkins; 2000. 787 p.

23. CLSI. Performance standards for antimicrobial susceptibility testing. 30th ed. Wayne PA: Clinical and Laboratory Standards Institute; 2019. 332 p.

24. American Society for Microbiology. ASM style manual for journals and books. Washington, DC: American Society for Microbiology; 1985. 190 p.

25. Naber KG, Holfstetter A. Recommended standards in diagnosis and therapy of urinary tract infections. Eur Urol. 1998; 34(1): 1-6.

26. Reid G, Brigidi P, Burton JP, Contractor N, Duncan S, Fargier E, et al. Microbes central to human reproduction. Am J Reprod Immunol. 2015; 73(1): 1-11.

27. Peric A, Weiss J, Vulliemoz N, Baud D, Stojanov M. Bacterial Colonization of the Female Upper Genital Tract. International Journal of Molecular Sciences. 2019; 20(14): 34-45.

28. Linhares IM, Witkin SS, Giraldo P. Bacterial flora of the female genital tract: function and immune regulation. Best Pract Res Clin Obstet Gynaecol. 2007; 21(1): 347-54.

29. Witkin SS. The vaginal microbiome, vaginal anti-microbial defence mechanisms and the clinical challenge of reducing infection-related preterm birth. Best Pract Res Clin Obstet Gynaecol. 2015; 122(2): 213-8.

30. Marchesi JR, Ravel J. The vocabulary of microbiome research: a proposal. Microbiome. 2015; 3(31): $123-8$.

31. Dasari S, Anandan SK, Rajendra W, Valluru L. Role of microbial flora in female genital tract: a comprehensive review. Asian Pacific J Trop Dis. 2016; 6(6): 909-17.

32. Mändar R. Microbiota of male genital tract: impact on the health of man and his partner. Pharmacol Res. 2013; 69(11): 32-41.

33. De Francesco MA, Negrini R, Ravizzola G, Galli P, Manca N. Bacterial species present in the lower male genital tract: a fiveyear retrospective study. Eur J Contracept Reprod Health Care. 2011; 16(1): 47- 53.

34. Askienazy-Elbhar M. Male genital tract infection: the point of view of the bacteriologist. Gynecol Obstet Fertil. 2005; 33(9): 691-7.

35. Purvis K, Christiansen $\mathrm{E}$. Infection in the male reproductive tract. Impact, diagnosis and treatment in relation to male infertility. Int J Androl. 2020; 16(1): 1-13.

36. Carlet J, Pulcini C, Piddock LJV. Antibiotic resistance: A geopolitical issue. Clin Microbiol Infect. 2014; 20(10): 949-53.

37. Opal SM. Non-antibiotic treatments for bacterial diseases in an era of progressive antibiotic resistance. Crit Care. 2016; 20(1): 10-2.

38. Hulscher ME, Grol RP, Vandermeer JW. Antibiotic prescribing in hospitals: a social and behavioural scientific approach. Lancet Infect Dis. 2010; 10(3): 167-75.

39. Bondar MV, Pilipenko MM, Svintukovskiy MYu, Kharchenko LA, Previsla OM, Tsvik IM. Antibiotikorezistentnist mikroorganizmiv: mekhanizmi rozvitku y shlyakhi zapobigannya [Antibiotic-resistant microorganism: mechanisms of development and paths for getting rid of]. Meditsina neotlozhnykh sostoyaniy. 2016; 3(3): 11-7. [Ukrainian]

40. Andrukh VS, Andrukh VN. Antibiotiki i antibiotikorezistentnist: problemi i shlyakhi virishennnya [Antibiotics and antibiotic resistance: problems and ways of life]. Dityachiy likar. 2017; 4(4): 32-6. [Ukrainian]

41. Gumenyuk MI, Denisov OS, Feshchenko Yul. Antibiotikorezistentnist mikroorganizmiv. Stan problemi ta shlyakhi virishennya [Antibiotic-resistant microorganisms. Problem status and solutions]. Ukrayinskiy khimioterapevtichniy zhurnal. 2010; 1(23): 4-10. [Ukrainian] 
42. Supotnitskiy MV. Mekhanizmy razvitiya rezistentnosti $\mathrm{k}$ antibiotikam $\mathrm{u}$ bakteriy [Mechanisms for the development of antibiotic resistance in bacteria]. Biopreparaty. 2011; 2(2): 4-44. [Russian]

43. Komolafe OO. Antibiotic resistance in bacteria - an emerging public health problem. Malawi Med J. 2003;15(2): 63-7.

44. Amyes SGB. The rise in bacterial resistance. Brit Med J. 2000; 320(10): 199-200.

45. Laxminarayan R. Antibiotic resistance: the need for global solutions. Lancet Infect Dis. 2013; 13(12): 1057-98.

46. Malik B, Bhattacharyya S. Antibiotic drug-resistance as a complex system driven by socio-economic growth and antibiotic misuse. Sci Rep. 2019; 9(1): 151-84.

47. Martínez JL, Baquero F. Interactions among strategies associated with bacterial infection: pathogenicity, epidemicity, and antibiotic resistance. Clin Microbiol Rev. 2018; 15(4): 647-79.

48. Gergova RT, Strateva TV, Mitov IG. Gardnerella vaginalis-associated bacterial vaginosis in Bulgarian women. The Brazilian Journal of Infectious Diseases. 2013; 17(3): 307-13.

49. Teixeira GS, Carvalho FP, Arantes RM, Nunes AC, Moreira JL, Mendonca M, et al. Characteristics of Lactobacillus and Gardnerella vaginalis from women with or without bacterial vaginosis and their relationships in gnotobiotic mice. J Med Microbiol. 2012; 61(1): 1074-81.

50. Janulaitiene M, Paliulyte V, Grinceviciene S, Zakareviciene J, Vladisauskiene A, Marcinkute A, et al. Prevalence and distribution of Gardnerella vaginalis subgroups in women with and without bacterial vaginosis. BMC Infect Dis. 2017; 17(1): 389-94.

51. Gruzevsky OA, Vladimirova MP. The results of a complex bacteriological study of vaginal contents under the conditions of bacterial vaginosis. Advances in biology and medicine. 2014; 2(2): 54-7.

52. Manzoor S, Aziz M, Sheikh AS. Identification and Characterization of Candida on CHROM Agar ${ }^{\mathrm{TM}}$ in Pregnant Women of Multan, Pakistan. J Women's Health Care. 2018; 7(1): 2-8.

53. Okodo M, Kawamura J, Okayama K, Kawai K, Fukui T, Shiina N, et al. Cytological features associated with ureaplasma urealyticum in pap cervical smear. Asian Pac J Cancer Prev. 2017; 18(8): 2239-42.

54. Kiessling AA, Desmarais BM, Yin HZ, Loverde JJ, Eyre RC. Detection and identification of bacterial DNA in semen. Fertility and Sterility. 2008; 90(5): 1744-56.

УДК 579.61:616.62-002]=111

МОНІТОРИНГ РОЗПОВСЮДЖЕННЯ АНТИБІОТИКОРЕЗИСТЕНТНИХ ШТАМІВ МІКРООРГАНІЗМІВ - ЗБУДНИКІВ ІНФЕКЦІЙНИХ ПРОЦЕСІВ УРОГЕНІТАЛЬНОЇ СИСТЕМИ ПАЦІЄНТІВ

Виноградова К. О., Гаврилюк В. Г., Хлопова О. В., Погорєлова А. М., Скляр Т. В., Соколова І. $€$.

Резюме. 3 метою визначення частоти інфекційних уражень урогенітального тракту було обстежено 176 осіб різного віку та статі - пацієнтів Лікувально-діагностичного центру на базі Дніпровської медичної академії (м. Дніпро) протягом (01.01-31.08) 2020 року. За результатами проведеного мікробіологічного дослідження встановлено факт розвитку інфекційних процесів у 86 осіб, що складало 32,31\% випадків. При вивченні мікробного пейзажу репродуктивної системи обстежених пацієнтів визначено спектр пріоритетних збудників урогенітальних інфекцій: у дітей і підлітків - Klebsiella oxytoca, Haemophilus influenzae / H. parainfluenzae, Escherichia coli, Streptococcus agalactiae; у жінок - Candida albicans, Streptococcus agalactiae, Escherichia coli, Ureaplasma spp.; у чоловіків - Ureaplasma spp. та Escherichia coli. При проведенні моніторингу розповсюдження антибіотикорезистентних варіантів мікроорганізмів - збудників інфрекційних процесів встановлено найвищі рівні стійкості у виділених клінічних ізолятів по відношенню до препаратів класів: фрторхінолонів - 29,16\%, цефралоспоринів - 18,75\% та карбопенемів - 10,42\% випадків.

3 використанням тест-систем «Фемофрлор» та «Андрофлор» досліджено видовий спектр збудників дисбіотичних станів урогенітального тракту у 88 пацієнтів віком 17-75 років за допомогою полімеразної ланцюгової реакції в режимі реального часу. Показано частоту виявлення умовно-патогенних $\mathrm{i}$ патогенних мікроорганізмів із урогенітальної сфери жінок і чоловіків та співвідношення аеробної й анаеробної мікробіоти при дисбіотичних синдромах. За результатами дослідження у $60,97 \%$ жінок та $76,59 \%$ чоловіків було зафіксовано значні відхилення в бік зниження титрів представників симбіотичної мікробіоти - бактерій роду Lactobacillus на фоні підвищення кількісних показників умовно-патогенних мікроорганізмів Gardnerella vaginalis etc., Eubacterium spp., Ureaplasma spp., Candida spp., Anaerococcus spp., Bacteroides spp. etc., Enterobacterium spp., і наявності патогенних мікроорганізмів Мусораsта genitalium, Trichomonas vaginalis, Chlamydia trachomatis, Ureaplasma parvum у значних титрах.

Ключові слова: урогенітальний тракт, мікробіота, антибіотикорезистентність, ПЛР в режимі реального часу. 
Удк 579.61:616.62-002]=111

МОНИТОРИНГ РАСПРОСТРАНЕНИЯ АНТИБИОТИКОРЕЗИСТЕНТНЫХ ШТАММОВ МИКРООРГАНИЗМОВ - ВОЗБУДИТЕЛЕЙ ИНФЕКЦИОННЫХ ПРОЦЕССОВ УРОГЕНИТАЛЬНОЙ СИСТЕМЫ ПАЦИЕНТОВ

Виноградова К. О, Гаврилюк В. Г., Хлопова Е. В., Погорелова А. Н., Скляр Т. В., Соколова И. Е.

Резюме. С целью определения частоты инфрекционных поражений урогенитального тракта было обследовано 176 человек разного возраста и пола - пациентов Лечебно-диагностического центра на базе Днепровской медицинской академии (г. Днепр) в течение (01.01-31.08) 2020 года. По результатам проведенного микробиологического исследования установлен факт развития инфекционных процессов у 86 человек, что составляло $32,31 \%$ случаев. При изучении микробного пейзажа репродуктивной системы обследованных пациентов определен спектр приоритетных возбудителей урогенитальных инфекций: у детей и подростков - Klebsiella oxytoca, Haemophilus influenzae / H. parainfluenzae, Escherichia coli, Streptococcus agalactiae; у женщин - Candida albicans, Streptococcus agalactiae, Escherichia coli, Ureaplasma spp.; у мужчин - Ureaplasma spp. и Escherichia coli. При проведении мониторинга распространения антибиотикорезистентных вариантов микроорганизмов - возбудителей инфекционных процессов установлено высокие уровни устойчивости в выделенных клинических изолятов по отношению к препаратам классов: фрторхинолонов - 29,16\%, цефралоспоринов - 18,75\% и карбопенемам - 10,42\% случаев.

С использованием тест-систем «Фемофрлор» и «Андрофрлор» исследован видовой спектр возбудителей дисбиотических состояний урогенитального тракта у 88 пациентов в возрасте 17-75 лет с помощью полимеразной цепной реакции в режиме реального времени. Показано частоту выявления условно-патогенных и патогенных микроорганизмов с урогенитальной сферы женщин и мужчин и соотношение аэробной и анаэробной микробиоты при дисбиотических синдромах. По результатам исследования у $60,97 \%$ женщин и 76,59\% мужчин были зафриксированы значительные отклонения в сторону снижения титров представителей симбиотической микробиоты - бактерий рода Lactobacillus на фоне повышения количественных показателей условно-патогенных микроорганизмов Gardnerella vaginalis etc., Eubacterium spp., Ureaplasma spp ., Candida spp., Anaerococcus spp., Bacteroides spp. etc., Enterobacterium spp., и наличия патогенных микроорганизмов Mycopasma genitalium, Trichomonas vaginalis, Chlamydia trachomatis, Ureaplasma parvum в значительных титрах.

Ключевые слова: урогенитальный тракт, микробиота, антибиотикорезистентнисть, ПЦР в режиме реального времени.

The authors of this study confirm that the research and publication of the results were not associated with any conflicts regarding commercial or financial relations, relations with organizations and/or individuals who may have been related to the study, and interrelations of coauthors of the article. 